\title{
Kandungan Antioksidan pada Kubis Merah (Brassica oleracea L.) Dan Aplikasinya Pada Pembuatan Kerupuk
}

\author{
Aldila Sagitaning Putri*, Endang Bekti Kristiani dan Sri Haryati \\ Jurusan Teknologi Hasil Pertanian, Universitas Semarang \\ Jl. Arteri Soekarno Hatta Tlogosari, Semarang, 50196 Indonesia \\ Email : peter3393@gmail.com
}

\begin{abstract}
Abstrak
Kubis Merah (Brassica oleracea L.) merupakan salah satu hasil pertanian yang mengandung kandungan antosianin yang berpotensi sebagai antioksidan. Tujuan yang hendak dicapai dalam penelitian ini adalah untuk menggali potensi kubis merah sebagai antioksidan alami pada kerupuk kubis merah. Tahapan dari penelitian ini adalah pembuatan kerupuk kubis merah dengan berbagai formulasi tepung tapioka dan kubis merah, uji organoleptik serta penentuan aktivitas antioksidan dan kadar antosianin. Hasil penelitian menunjukkan bahwa aktivitas antioksidan dari kubis merah dan kerupuk kubis merah sebesar. Dari uji organoleptik yang paling disukai panelis adalah perlakuan T2K1 yaitu 150 gram tapioka dan 50 gram kubis mera yang memiliki kadar air sebesar 15,49\%, kadar abu 1,18\%, kadar protein 1,48\%, kadar lemak 16,55\%, antosianin 1,31\% dan aktivitas antioksidan sebesar 23,93\%. Dengan demikian dapat disimpulkan bahwa kerupuk kubis merah memiliki potensi sebagai sumber antioksidan.
\end{abstract}

Kata kunci: kubis merah, antosianin, aktivitas antioksidan.

\begin{abstract}
Antioxidant content in Red Cabbage (Brassica oleracea L.) and Application In The Making of Crackers

Red Cabbage (Brassica oleracea L.) is one of the agricultural products containing anthocyanin content that has potential as antioxidant. The purpose of this study was to explore the potential of red cabbage as a natural antioxidant in red cabbage crackers. The stages of this research are the manufacture of red cabbage crackers with various formulations of tapioca flour and red cabbage, organoleptic test and the determination of antioxidant activity and anthocyanin levels. The results showed that antioxidant activity of red cabbage and red cabbage cracker amounted to. The most preferred organoleptic test of panelist is $T_{2} K_{1}$ treatment which is $150 \mathrm{~g}$ tapioca and $50 \mathrm{~g}$ of red cabbage which has water content 15,49\%, ash content 1,18\%, protein content 1,48\%, fat content $16,55 \%$, antocyanin $1.31 \%$ and antioxidant activity of $23.93 \%$. Thus it can be concluded that red cabbage crackers have the potential as a source of antioxidants.
\end{abstract}

Keywords: red cabbage, anthocyanin, antioxidant activity.

\section{PENDAHULUAN}

Kubis merah (Brassica oleracea L.)
merupakan salah satu hasil pertanian yang
keberadaannya kini cukup dikenal oleh
masyarakat. Jumlah produksi kubis merah
dilndonesia relatif rendah, hal ini disebabkan

kurangnya permintaan konsumen terhadap komoditas ini. Kubis merah di Indonesia pemanfaatannya hanya terbatas untuk pembuatan sayur asin dan sebagai campuran dalam salad. Seiring dengan perkembangan jaman, masih banyak masyarakat belum mengetahui manfaat dari kubis merah tersebut, salah satunya dalam 
pembuatan kerupuk dari kubis ungu. Pemanfaatan kubis merah dalam pembuatan kerupuk tersebut adalah salah satu bentuk eksplorasi potensi tanaman di Indonesia dengan menggunakan kerupuk kubis merah sebagai makanan selingan maupun sebagai variasi dalam lauk pauk. Pada umumnya kerupuk dikonsumsi sebagai makanan tambahan untuk lauk pauk atau sebagai makanan kecil. Salah satu faktor utama yang menentukan mutu kerupuk adalah kerenyahannya. Semua konsumen menginginkan kerupuk yang renyah, artinya yang menimbulkan bunyi sewaktu digigit dan dikunyah (Koswara, 2009).

Akhir-akhir ini banyak usaha dilakukan untuk mengatasi masalah ketergantungan pada suatu bahan pangan pokok saja, hal ini disebabkan karena usaha penganekaragaman pangan memegang peranan penting. Seperti halnya di Indonesia, pemanfaatan kubis merah sebagai bahan makanan fungsional belum dilakukan secara optimal. Dalam penelitian ini, masalah ketergantungan tersebut dapat diatasi dengan mengolah beberapa sayuran, dalam hal ini adalah kubis merah, yang nantinya akan diolah menjadi kerupuk kubis merah. Antosianin yang terdapat dalam kubis merah berpotensi sebagai pewarna alami merah pada bahan pangan yang memiliki sisi positif sebagai antioksidan terhadap radikal bebas (Senja et al., 2014).

Tujuan yang hendak dicapai dalam penelitian ini adalah untuk menggali potensi kerupuk kubis merah sebagai antioksidan alami serta untuk mengetahui beberapa komposisi kimiawi dan sifat fisik dari kerupuk kubis merah. Manfaat dari penelitian ini adalah dapat memperkaya ilmu pengetahuan dengan mengetahui aktivitas antioksidan dari kubis merah dan aplikasinya dalam pembuatan kerupuk kubis merah serta peningkatan pemanfaatan kerupuk kubis merah sebagai makanan fungsional dan mengetahui nilai ekonomis tinggi dan manfaatnya sebagai produk makanan yang mempunyai potensi sebagai antioksidan.

\section{METODOLOG}

Bahan baku yang diperoleh dari penelitian ini adalah kubis merah dari Pasar Gang Baru, Semarang dengan umur panen 1 bulan. Bahan yang digunakan pada kerupuk kubis merah adalah tepung tapioka, kubis merah, garam dan penyedap rasa. Serta bahan kimia untuk analisa adalah metanol, larutan DPPH (1,1-diphenyl - 2pycrylhydrazil), sodium asetat, $\mathrm{HCl}$, metanol $-\mathrm{HCl}$ $1 \%$, aquadest, buffer $\mathrm{KCl} \mathrm{pH} 1$, buffer natrium asetat $\mathrm{pH}$ 4,5, BHT(Giusti dan Wrolstad, 2001). Peralatan yang utama adalah spektrofotometer UV-VIS (Shimadzu UV-1601), Llyod Instrument texture analyzer (Model $1000 \mathrm{~S}$, Lloyd Instrument Inc,UK), water batch dan alat-alat gelas lainnya.

Pembuatan kerupuk kubis merah mengacu pada Endang (2015) dengan modifikasi sebagai berikut: kubis merah dicuci, kemudian dirajang halus. Ditimbang sesuai formulasi kerupuk kubis merah. Ditambahkan sedikit garam dan penyedap rasa. Langkah berikutnya adalah diblender dan ditambahkan sedikit air hingga membentuk adonan. Cetak adonan ke dalam tapioc yang telah dilapisi tapioca, dikukus hingga matang $( \pm 45$ menit). Setelah itu didinginkan kemudian dipotong tipis-tipis dan dijemur di bawah terik matahari hingga kering dan kerupuk kubis merah siap untuk digoreng. Formulasi Kerupuk Kubis Merah dapat dilihat pada Tabel 1.Rancangan percobaan pada pembuatan kerupuk kubis merah menggunakan pola faktorial dengan Rancangan

Tabel 1. Formulasi Kerupuk Kubis Merah

\begin{tabular}{lcccccc}
\hline \multicolumn{1}{c}{ Bahan } & $\mathrm{T}_{1} \mathrm{~K}_{1}$ & $\mathrm{~T}_{1} \mathrm{~K}_{2}$ & $\mathrm{~T}_{2} \mathrm{~K}_{1}$ & $\mathrm{~T}_{2} \mathrm{~K}_{2}$ & $\mathrm{~T}_{3} \mathrm{~K}_{1}$ & $\mathrm{~T}_{3} \mathrm{~K}_{2}$ \\
\hline Tepung Tapioka (g) & 100 & 100 & 150 & 150 & 200 & 200 \\
Kubis Merah (g) & 50 & 100 & 50 & 100 & 50 & 100 \\
Garam (g) & 3 & 3 & 3 & 3 & 3 & 3 \\
Air Panas (cc) & 50 & 50 & 50 & 50 & 50 & 50 \\
\hline
\end{tabular}

Keterangan. $\mathrm{T}_{1} \mathrm{~K}_{1}=$ Tapioka $100 \mathrm{~g}+$ kubis merah $50 \mathrm{~g}, \mathrm{~T}_{1} \mathrm{~K}_{2}=$ Tapioka $100 \mathrm{~g}+$ kubis merah $100 \mathrm{~g} ; \mathrm{T}_{2} \mathrm{~K}_{1}=$ Tapioka $150 \mathrm{~g}$ + kubis merah $50 \mathrm{~g} ; \mathrm{T}_{2} \mathrm{~K}_{2}=$ Tapioka $150 \mathrm{~g}$ + kubis merah $100 \mathrm{~g} ; \mathrm{T}_{3} \mathrm{~K}_{1}=$ Tapioka $200 \mathrm{~g}+$ kubis merah $50 \mathrm{~g} ; \mathrm{T}_{3} \mathrm{~K}_{2}=\mathrm{Tapioka}$ $200 \mathrm{~g}+$ kubis merah $100 \mathrm{~g}$ 
Acak Kelompok (RAK) dengan 1 jumlah tapioka dengan 3 level dan faktor kedua jumlah kubis merah dengan 2 level. Perlakuan sebanyak 6 kombinasi yang diuji coba dan diulang 3 kali, perlakuan tersebut adalah Faktor pertama jumlah tepung tapioka, $\mathrm{T} 1=$ tepung tapioca $100 \mathrm{gram}$, $\mathrm{T} 2$ = tepung tapioka 150 gram, $\mathrm{T} 3$ = tepung tapioka 200 gram. Faktor kedua jumlah kubis merah : $\mathrm{K} 1=$ kubis merah 50 gram, $\mathrm{K} 2=$ kubis merah 100 gram

\section{HASIL DAN PEMBAHASAN}

\section{Tingkat Kesukaan kerupuk kubis merah}

Karakteristik mutu yang diuji meliputi warna, bau, rasa, tekstur dan secara keseluruhan dengan menggunakan panelis sebanyak 20 panelis. Tingkat kesukaan kerupuk kubis merah pada berbagai proporsi tepung tapioka dan kubis merah dapat dilihat pada Tabel 2 .

Pada Tabel 2, dapat dilihat bahwa proporsi tepung tapioka dan kubis merah $\mathrm{T}_{2} \mathrm{~K}_{1}(150: 50$ ) adalah produk kerupuk kubis merah yang paling disukai oleh panelis dalam uji kerenyahan, aroma dan kesukaan. Dari Tabel 2, dapat dilihat bahwa penambahan kubis merah berpengaruh nyata terhadap tingkat kesukaan dan tidak memberikan pengaruh yang nyata terhadap tingkat kerenyahan dan aroma.

\section{Komposisi Kimia Kerupuk Kubis Merah dengan Proporsi Tepung Tapioka dan Kubis Merah (150:50)}

Hasil analisis komposisi kimia dari kerupuk kubis merah yang paling disukai panelis dapat dilihat pada Tabel 3. Kadar air suatu bahan pangan yang cukup tinggi menyebabkan produk termasuk dalam bahan pangan yang mudah mengalami kerusakan, sedangkan kadar air yang rendah memungkinkan bahan pangan dapat bertahan lama. Pada Tabel 3 dapat dilihat bahwa kadar air tertinggi adalah kubis merah dari pada kerupuk mentah dan kerupuk matang. Hal ini disebabkan karena adanya proses penjemuran maupun proses pembuatan kerupuk yang mengakibatkan kadar air semakin berkurang. Kadar air secara signifikan juga mempengaruhi sifat tekstur bahan (Purwanto, 2015).
Tabel 2. Tingkat Kesukaan (kerenyahan, kesukaan dan aroma) kerupuk kubis merah pada berbagai proporsi tepung tapioka dan kubis merah

\begin{tabular}{cccc}
\hline Sampel & Kerenyahan & Kesukaan & Aroma \\
\hline $\mathrm{T}_{1} \mathrm{~K}_{1}$ & $3,35 \pm 1,49^{\mathrm{a}}$ & $3,90 \pm 1,21^{\mathrm{a}}$ & $3,55 \pm 1,05^{\mathrm{ab}}$ \\
$\mathrm{T}_{1} \mathrm{~K}_{2}$ & $3,85 \pm 1,35^{\mathrm{ab}}$ & $3,75 \pm 1,16^{\mathrm{a}}$ & $3,60 \pm 0,99^{\mathrm{a}}$ \\
$\mathrm{T}_{2} \mathrm{~K}_{1}$ & $4,40 \pm 0,99^{\mathrm{a}}$ & $4,35 \pm 1,18^{\mathrm{b}}$ & $4,25 \pm 1,25^{\mathrm{ab}}$ \\
$\mathrm{T}_{2} \mathrm{~K}_{2}$ & $4,15 \pm 1,04^{\mathrm{a}}$ & $3,90 \pm 1,21^{\mathrm{a}}$ & $3,75 \pm 1,16^{\mathrm{a}}$ \\
$\mathrm{T}_{3} \mathrm{~K}_{1}$ & $3,0 \pm 1,21^{\mathrm{b}}$ & $3,45 \pm 1,39^{\mathrm{a}}$ & $3,35 \pm 1,04^{\mathrm{ab}}$ \\
$\mathrm{T}_{3} \mathrm{~K}_{2}$ & $3,70 \pm 1,03^{\mathrm{a}}$ & $3,55 \pm 1,36^{\mathrm{a}}$ & $3,40 \pm 1,27^{\mathrm{a}}$ \\
\hline
\end{tabular}

Keterangan: superskrip dengan huruf yang berbeda pada kolom yang sama menunjukkan perbedaan yang nyata $(p<0,05)$.

Tabel 3. Komposisi Kimia Kerupuk Kubis Merah dengan proporsi tepung tapioka dan kubis merah (150: 50)

\begin{tabular}{cccc}
\hline Komposisi & $\begin{array}{c}\text { Kubis } \\
\text { Merah (\%) }\end{array}$ & $\begin{array}{c}\text { Kerupuk } \\
\text { Mentah (\%) }\end{array}$ & $\begin{array}{c}\text { Kerupuk } \\
\text { Matang } \\
(\%)\end{array}$ \\
\hline Kadar Air & 19,31 & 16,79 & 15,49 \\
Kadar Abu & 1,04 & 0,86 & 1,18 \\
Protein & 0,96 & 1,30 & 1,48 \\
Lemak & 0,10 & 1,34 & 16,55 \\
\hline
\end{tabular}

\section{Kadar Antosianin}

Penelitian tentang pelarut ekstraksi antosianin dari kubis merah menyimpulkan bahwa pelarut metanol $-\mathrm{HCl}$ merupakan pelarut teerbaik untuk mengekstrak antosianin (Oki, 2002). Pelarut ini memiliki gugus hidroksil yang akan membentuk ikatan intramolekuler dengan gugus hidroksil pada komponen fenolik sehingga akan meningkatkan kelarutan. Pemilihan pelarut metanol-HCl $1 \%$ juga didasarkan pada penelitian Giusti dan Wrolstad, 2001, yang menyatakan bahwa ekstraksi dengan pelarut ini menghasilkan ekstrak dengan aktivitas antioksidan dalam penangkapan radikal DPPH teringgi dibandingkan pelarut air, etanol, dan etil asetat.

Proses ekstraksi dilakukan dengan mencampur kubis merah dan pelarut dengan perbandingan 1:10. Pelarut yang digunakan adalah metanol-HCl 1\% (Kristiana et al, 2012). Proses maserasi dilakukan pada suhu $4^{\circ} \mathrm{C}$ dengan 
tujuan untuk menjaga kestabilan antosianin dan berdasarkan penelitian (Revilla, 1998) suhu tersebut sadalah suhu paling optimal untuk ekstraksi antosianin. Ekstrak metanol- $\mathrm{HCl} 1 \%$ mempunyai serapan maksimum pada $280 \mathrm{~nm}$ dan pada $536 \mathrm{~nm}$, yang merupakan daerah serapan yang khas untuk antosianin. Warna ekstrak merah tua menunjukkan tingginya antosianin yang terekstrak.

Dari hasil kadar antosianin yang diperoleh, dapat diketahui bahwa kadar antosianin pada kubis merah lebih besar dibandingkan kerupuk mentah maupun kerupuk matang, seperti yang terlihat pada Tabel 4. Hal ini disebabkan karena adanya faktor panas yang menyebabkan beberapa komponen antosianin akan mudah teroksidasi.

Keberadaan antosianin yang membentuk ikatan kompleks dengan gula atau senyawa lain pada ekstrak tergantung dari jenis pelarut yang digunakan. Antosianin juga dapat berikatan dengan antosianin yang lain maupun senyawa flavonoid lainnya. Kandungan antosianin yang tinggi tidak menjamin suatu bahan memiliki aktivitas antioksidan yang tinggi, oleh karena itu diperlukan pengujian aktivitas antioksidan.

Antosianin biasanya memang disarankan untuk diekstrak dengan pelarut polar yang bersifat asam seperti methanol- $\mathrm{HCl} 1 \%$ (Espada et al, 2004) yang menyatakan bahwa ekstraksi dengan menggunakan pelarut ini menghasilkan ekstrak dengan aktivitas antioksidan dalam penangkapan radikal DPPH tertinggi dibandingkan pelarut air, etanol dan etil asetat. Disamping itu selain pelarut, faktor yang mempengaruhi tingginya antioksidan adalah tingginya kadar antosianin dalam bahan (Oki, 2002)

Dari hasil kadar antosianin yang diperoleh, dapat diketahui bahwa kadar antosianin kubis merah lebih besar dibandingkan pada kerupuk mentah dan kerupuk matang, seperti yang terlihat pada Tabel 4. Hal ini disebabkan karena adanya faktor panas yang menyebabkan beberapa komponen antosianin akan mudah teroksidasi.

\section{Aktivitas Antioksidan}

Dalam penelitian ini, kemampuan menangkap radikal DPPH dari suatu bahan dinyatakan sebagai \% kapasitas penangkapan radikal. Semakin besar \% penangkapan radikal, maka aktivitasnya semakin tinggi. Hasil pengukuran aktivitas antioksidan metode DPPH (Tabel 5).

Dosis yang mampu menangkap radikal DPPH masing-masing sampel adalah 200 ppm yaitu $86,98 \%$ untuk kubis merah, 52,42\% untuk kerupuk mentah dan 23,93\% untuk kerupuk matang. Penelitian ini menggunakan BHT sebagai control. Pemilihan BHT karena merupakan antioksidan sintetis yang umum dipergunakan. Dari hasil yang diperoleh dapat dilihat bahwa aktivitas antioksidan dari kubis merah lebih besar dibandingkan dengan kontrol positifnya yaitu sebesar 50,21\%. Hal ini kemungkinan karena ekstrak mengandung antosianin yang mampu mendonorkan atom hidrogen sehingga akan mengubah DPPH menjadi non radikal (Chun, 2006). Hal ini didukung oleh beberapa penelitian yang menyatakan bahwa komponen antosianin yang terkandung dalam suatu bahan mampu menangkap radikal yang mengandung antosianin dan mampu menangkap radikal DPPH sebesar 88,23\% (Lestario et al., 2008). Buah duwet yang diekstrak dengan menggunakan methanol- $\mathrm{HCl} 1 \%$ mampu menangkap radikal DPPH sebesar 93\%, hal ini disebabkan karena buah duwet mengandung senyawa antosianin (Abou et al, 2011). Kubis merah mengandung antosianin yang menimbulkan perubahan warna pada suasana

Tabel 4. Kadar Antosianin dari Kubis Merah, Kerupuk Mentah dan Kerupuk Matang

\begin{tabular}{lc}
\hline \multicolumn{1}{c}{ Sampel } & $\begin{array}{c}\text { Kadar Antosianin } \\
(\mathrm{mg} / 100 \mathrm{gram})\end{array}$ \\
\hline Kubis Merah & 37,07 \\
Kerpuk Mentah & 1,534 \\
Kerpuk Matang & 1,312 \\
\hline
\end{tabular}

Tabel 5. Persen Penangkapan Radikal DPPH pada Kubis Merah, Kerupuk Mentah dan Kerupuk Matang

\begin{tabular}{cc}
\hline Sampel & Aktivitas Antioksidan (\%) \\
\hline Kubis Merah & 86,98 \\
Kerupuk Mentah & 52,42 \\
Kerupuk Matang & 23,93 \\
\hline
\end{tabular}


asam maupun basa bergantung pada jenis ikatan quinoidal, flavilium, chalcone dan pseudobase (Lopez et al., 2011).

Ekstrak metanol- $\mathrm{HCl} 1 \%$ yang berwarna merah tua, menunjukkan tingginya kadar antosianin. Hal ini diduga karena senyawa antioksidan dominan pada kerupuk kubis merah adalah antosianin. Menurut Lukitasari (2017) menyatakan bahwa kubis merah mengandung vitamin ( $A, B, C$ dan $E)$, mineral ( $K, C a, P, N a$ dan $\mathrm{Fe}$ ) sulfofaran dan flavonoid termasuk antosianin yang dapat menunjang aktivitas antioksidan saat pengujian).

\section{KESIMPULAN}

Kerupuk kubis merah yang dibuat dengan campuran tepung tapioka $150 \mathrm{~g}$ dan kubis merah $50 \mathrm{~g}$ lebih disukai oleh panelis dari pada formulasi yang lain. Kerupuk kubis merah yang paling disukai oleh panelis memiliki kadar air sebesar $15,49 \%$, kadar abu 1,18\%, kadar protein 1,48\%, kadar lemak 16,55\%, kadar antosianin 1,31\% dan aktivitas antioksidan sebesar $23,93 \%$.

\section{UCAPAN TERIMA KASIH}

Penulis mengucapkan terimakasih kepada LPPM (Lembaga Penelitian dan Pengabdian kepada Masyarakat) Universitas Semarang yang telah mendanai penelitian ini sehingga terlaksana dengan baik dan lancar, serta seluruh dosen Fakultas Teknologi Hasil Pertanian, Universitas Semarang yang telah memberikan motivasi sehingga dapat berjalan dengan sukses.

\section{DAFTAR PUSTAKA}

Abou-Arab, A.A., Abu-Salem, F.M. \& Abou-Arab, E.A., 2011. Physico-chemical properties of natural pigments (anthocyanin) extracted from Roselle calyces (Hibiscus subdariffa). Journal American Science 7(7):445-456.

Chun, O.K., Kim, D.O. \& Lee, C.Y., 2003. Superoxide radical scavenging activity of the major polyphenols in fresh plums. Journal Agricultural And Food Chemistry. 51(27): 8067-8072.

Endang, B.K. 2015. Penggunaan Jumlah Mocaf dan Lobak (Raphanus sativus L.) Dalam
Pembuatan Kerupuk Terhadap Sifat Fisik dan Organoleptik. Jurnal Teknologi Pangan Hasil Pertanian. 12(2)

Espada, M.A.C., Wood, K.V., Bordelon, B. \& Watkins, B.A., 2004. Anthocyanin quantification and radical scavenging capacity of Concord, Norton, and Marechal Foch grapes and wines. Journal of Agricultural And Food Chemistry. 52(22):6779-6786.

Giusti, M.M. \& Wrolstad, R.E. 2001. Characterization And Measurement Of Anthocyanins by UV-Visible Spectroscopy. Journal Current Protocol in Food Analytical Chemistry, page F1.2.1-F1.2.13.

Kristiana, H.D., Ariviani, S. \& Khasanah, L.U., 2012. Ekstraksi pigmen antosianin buah senggani (Melastoma malabathricum auct. Non linn) dengan variasi jenis pelarut.J. Teknosains Pangan. 1(1):105-109.

Koswara, S. 2009. Pengolahan Aneka Kerupuk. Jakarta.

Lestario, L.N., Sugiarto, S. \& Timotius, K.H., 2008. Aktivitas Antioksidan Dan Kadar Fenolik Total Dari Ganggang Merah (Gracilaria verrucosa L). Jurnal Teknologi Industri Pangan. 19(2):131-138.

Lopes, T.J., Yaginuma, S.R., Quadri, M.G.N. \& Quadri, M.B., 2011. Evaluation of red cabbage anthocyanins after partial purification on clay. Brazilian Archives of Biology and Technology. 54(6):1349-1356. DOI : 10.1590 /S1516-89132011000600022.

Lukitasari, D.M., Indrawati, R., Chandra, R.D. \& Limantara, L., 2017. Mikroenkapsulasi Pigmen Dari Kubis Merah: Studi Intensitas Warna Dan Aktivitas Antioksidan. Jurnal Teknologi dan Industri Pangan. 28(1):1-9

Oki, T., Masuda, M., Furuta, S., Nishiba, Y., Terahara \& Suda, I. 2002. Involvement of Anthocyanin and Other Phenolic Compounds in Radical Scavenging Activity of Purple Fleshed Sweet Potato Cultivars. Journal of Food Science. 67:1752-1756.

Purwanto, E. 2015. Kimia Pangan Air dalam Bahan Pangan. Jakarta.

Revilla, E., Ryan, J.M. \& Martín-Ortega, G., 1998. Comparison of several procedures used for the extraction of anthocyanins from red grapes. Journal of Agricultural and Food Chemistry. 46(11):4592-4597. 
Senja, R.Y., Issusilaningtyas, E., Nugroho, A.K. \& Setyowati, E.P., 2014. Perbandingan Metode Eks-traksi dan Variasi Pelarut terhadap Rendemen dan Aktivitas Antioksidan Ekstrak
Kubis Ungu (Brassica oleracea L. Var. Capitata F. rubra). Traditional Medicine Journal. 19(1):43-48. 